\title{
TAXONOMIC NOTES ON THE GENUS Euaspis Gerstäcker (Hymenoptera: Apoidea: Megachilidae) FROM VIETNAM
}

\author{
Tran Thi Ngat", Khuat Dang Long, Nguyen Thi Phuong Lien \\ Institute of Ecology and Biological Resources, Vietnam Academy of Science and Technology
}

\begin{abstract}
Taxonomic notes on species of the genus Euaspis Gerstäcker, 1858 (Hymenoptera: Megachilidae) from Vietnam are presented. Three species of the genus are reported: $E$. aequicarinata Pasteels is recorded in the central highlands Vietnam (Kon Tum Province) beside the previous record of this species in the northwest (Hoa Binh Province); E. polynesia Vachal is widely recorded throughout Vietnam; the taxonomy of Vietnamese Euaspis basalis (Ritsema, 1874) is a misidentification, and it is indeed Euaspis diversicarinata Pasteels, 1980 and is a new record from Vietnam. A key to the females of Vietnamese species of Euaspis Gerstäcker and a redescription of the female of $E$. diversicarinata are given with illustrations.

Keywords: Apoidea, Megachilidae, Euaspis, new record, Vietnam.
\end{abstract}

Citation: Tran Thi Ngat, Khuat Dang Long, Nguyen Thi Phuong Lien, 2016. Taxonomic notes on the genus Euaspis Gerstäcker (Hymenoptera: Apoidea: Megachilidae) from Vietnam. Tap chi Sinh hoc, 38(4): 515-520. DOI: $10.15625 / 0866-7160 / \mathrm{v} 38 \mathrm{n} 4.8948$.

*Corresponding author: tranthingat1012@gmail.com

Received 30 November 2016, accepted 26 December 2016

\section{INTRODUCTION}

Wild bees are diverse and important in nature. Currently, however, diversity and their conservation status of bees from Vietnam are poorly studied (Le Xuan Hue, 2010; Khuat Dang Long et al., 2004; Khuat Dang Long et al., 2012), and megachiline bees are no an exception.

Genus Euaspis Gerstäcker, 1858 comprises 12 described species worldwide. Of them, two species are distributed in Africa and ten species are found in Asia (Ascher \& Pickering, 2016; Michener, 2007). This genus is widespread in Africa, south and eastern Asia, from Nepal, India, Sri Lanka east through Indonesia to the Moluccas and Kai and north through the Philippines, Taiwan, Japan, Korea, China (Michener, 2007). Euaspis resembles Pachyanthidium in the following characters: red metasoma, flat scutellum and the distally enlarged but round male gonostyli, the trilobed male sternum 7, two apical spines on the fore and middle tibiae. However, Euaspis can be distinguished from Pachyanthidium in lacking a scopa, a carina or lamella on the preoccipital ridge behind the vertex and a broad toothed apex of the mandible of the female, in having the juxtantennal carinae and a vertical carina on the mesepisternum in front of the middle coxa. Euaspis parasitizes species of the genera Lithurgus and chalicodomiform Megachile (Michener, 2007).

In previous studies, three species of this genus were recorded in Vietnam: Euaspis aequicarinata Pasteels, E. basalis (Ritsema) and E. polynesia Vachal. In this study, a misidentification is corrected.

\section{MATERIALS AND METHODS}

Bee specimens examined in the present study is deposited in the Hymenoptera collections of the Institute of Ecology and Biological Resources (IEBR), Ha Noi, Vietnam. The materials were collected by sweeping net from various surveys in the north and south Vietnam.

Morphological and color characters of the pinned and dried specimens were observed under a dissecting stereomicroscope. Body length refers the length of head and first two metasomal segments combined. Photographic images were made with a Leica M80 Digital 
Stereo Microscope (Leica Microsystems GmbH, Wetzlar, Germany), using LAS exclusive microscopy software (LAS EZ 3.1.1); the plates were edited using Photoshop CS6. The following abbreviations are used, NE: northeast, NP: National Park, NR: Nature Reverse; S and $\mathrm{T}$ refer to numbered metasomal sterna and metasomal terga, respectively; for the morphological terminology used in this paper, see Michener (2007); and 'Apoi. + number' = code number indexing for specimens of the Apoidea in the collection.

\section{RESULTS AND DISSCUSION}

Taxonomy

Key to the females of Vietnamese species of Euaspis Gerstäcker

1a. S6 without well-defined basal platform and well-developed laterobasal teeth (fig. 9) ..............................................Euaspis polynesia Vachal, 1903

1b. S6 with well-defined basal platform, weak or absent laterobasal teeth.......................2

2a. Clypeus with a median longitudinal stout keel (fig. 1). Spots on of lateral margins of scutellum and lateral margins of axillae pale yellow (fig. 2). Basal platform of S6 strongly raised and occupying the main part of the disc (fig. 3)

E. aequicarinata Pasteels, 1980

2b. Clypeus without a median longitudinal stout keel (fig. 4). Lateral margins of scutellum and axillae black (fig. 5). Platform of S6 subrectangular, strongly raised apically, apex of S6 subacute (fig. 6).

E. diversicarinata Pasteels, 1980

\section{Systematics}

Genus Euaspis Gerstäcker, 1858

Euaspis Gerstäcker, 1858: 461. Type species: Thynnus abdominalis Fabricius, 1793, by original designation.

Diagnosis. Diagnosis of the genus Euaspis was given by Michener (2007) as follows: Body black, sometimes faintly bluish, and lack of yellow markings, but the metasoma commonly red. The interantennal area elevated, with a strong, curved juxtantennal carina mesal to each antennal base and also with a smooth, longitudinal, median ridge or carina. Hind coxa with a strong longitudinal carina on the inner margin, outer surface strongly expanded laterally to form a projecting lobe. Scutellum strongly produced posteriorly, projecting over the propodeum. Scopa absent. T7 of the male trilobed, small, extending little beyond T6.

Euaspis aequicarinata Pasteels, 1980 (Figs 13)

Euaspis aequicarinata Pasteels, 1980: 78, 87, Sabah: $q$ (holotype), in the Natural History Museum, London.

Euaspis aequicarinata is known to occur in China, Laos, Thailand, Malaysia and Java
(Ascher \& Pickering, 2016; Baker, 1995). In Vietnam, this species was recorded by Baker (1995) based on a specimen collected in northwest Vietnam, Hoa Binh Province (Tonkin, Hoabinh [Tongking Hoa Binh], Agu. 1918, R. V. de Salvaza). In this study, this species is reconfirmed to occur in Vietnam, in Kon Tum Province as a new distribution record.

Material examined. Kon Tum: 19 , Chu Mom Ray NP, Sa Thay, 19 47'24.5'N, $104^{\circ} 59^{\prime} 46.5^{\prime}$ 'E, 729m, 25.iv.2016, Nguyen TP Lien, Nguyen D Dai, Tran T Ngat.

Diagnosis. Female: Clypeus with a median longitudinal stout keel (fig. 1). Scutellum subtrucate, with the median apical depression obsolete (fig. 2). S6 with large, sharply margined, strongly raised platform, occupying the main part of the disc (fig. 3). Scutellum with very coarse punctures (fig. 2). Spots on lateral margins of scutellum and lateral margins of axillae pale yellow (fig. 2).

\section{Euaspis diversicarinata Pasteels, 1980 (Figs 4-} 6)

Euaspis diversicarinata Pasteels, 1980: 78, 80, Sabah: + (holotype), in the Natural History Museum, London.

This species is only known to occur in 
Sabah Province of Malaysia (Baker, 1995; Ascher and Pickering, 2016).

Material examined. 1q, 'Apoi.0325', NE Vietnam: Phu Tho, Tan Son, Son Dong, Acacia flower, 02.x.2011, PH Phong; Bac Giang: 1울 Khe Vang, An Lac, Son Dong, 21 18'46”N, $106^{\circ} 56^{\prime} \mathrm{E}$, 4.vi.2014, Nguyen TP Lien, Nguyen D Dai, Tran D Duong.

Based on a specimen collected in Phu Tho Province, Khuat Dang Long et al. (2012) recorded Euaspis basalis (Ritsema, 1874) from Vietnam. However, careful examination of the specimen allows us to conclude that it is indeed $E$. diversicarinata Pasteels, not E. basalis. Because in E. diversicarinata, latero-basal teeth of S6 vestiges and metasoma wholly red but in $E$. basalis, latero-basal teeth of $\mathrm{S} 6$ welldeveloped and T1 black. And in this study, E. divercarinata was so recorded with one female specimen in Bac Giang Province, northeast Vietnam.

Euaspis diversicarinata is recorded from Vietnam here for the first time. The female of this species was described in 1980 by Pasteels. In this study, the female is redescribed with illustrations.

Diagnosis. Female: Apical margin of scutellum with a medially shallow dimple (fig. 5). Platform of S6 subrectangular, strongly raised apically, apex of S6 subacute (fig. 6). Scutellum with dense, unequal punctures, with coarse and close punctures centrally, the punctures arranged to form longitudinal middle lines from near basal to near apical margins, a small dimple at apical margin medially, inside this dimple with minute punctures (fig. 5).

Redescription. Female: Body length: 11.5 $\mathrm{mm}$, fore wing length: $13 \mathrm{~mm}$. Frons with a short longitudinal median and faint carina. Supraclypeal area with a median longitudinal stout keel extending from antennal socket to base of clypeus (fig. 4 ). Clypeus shiny, without a median longitudinal stout keel. Apical margin of scutellum with a median shallow dimple (fig. 5). Platform of S6 subrectangular, strongly raised apically, apex of S6 subacute (fig. 6).

Clypeus with rather shiny, coarse and regular punctures (fig. 4). Mesosoma with subequally close dense punctures. Lateral margins of mesosoma with sparse punctures. Scutellum with dense, unequally punctures, with coarse and close punctures centrally, the punctures arranged to form longitudinal middle lines from near basal to near apical margins, a small dimple at apical margin medially, inside this dimple with minute punctures (fig. 5). Axillae with coarse and dense punctures, except its lateral margins with smaller punctures (fig. $5)$.

Body black except near apical vertical of mandible brown red, metasoma wholly red and all tarsi brownish red apically.

Lateral and apical margins of clypeus, paraocular area from apical margin to over antenna socket, genal area, fore and middle coxae, trochanter and fore femur ventrally with long pubescences. Basitarsus and all tarsi at inner side with red bristles and outer side with white bristles.

\section{Euaspis polynesia Vachal, 1903 (Figs 7-10)}

Euaspis polynesia Vachal, 1903a: 97, Celebes: $\sigma^{\lambda}$ (holotype), in the University Museum, Oxford.

Euaspis polynesia Vachal, 1903b: 173.

Euaspis polynesia is known to occur in China to Indonesia, and Japan (Ascher \& Pickering, 2015; Baker, 1995). In Vietnam, this species was recorded by Baker (1995) based on one female collected in Hoa Binh Province (Tonkin, Hoabinh, viii. 1918 (R. V. de Salvaza)) and by Ascher \& Pickering (2016) based on one female collected in Dong Nai Province (Trang Bom Arboretum, Bien Hoa, 1.ix.1932, M. Poilane), one female collected in Dak Lak Province (Dak Lak, 100m, 6.iv.2009, H. Ngo). In this study, this species is recorded in Dien Bien, Bac Kan, Son La, Phu Tho, Vinh Phuc, and Thanh Hoa as new records.

Material examined. Dien Bien: 1 q $21^{\circ} 26^{\prime} 43^{\prime \prime} \mathrm{N}, 103^{\circ} 02^{\prime} 42^{\prime \prime} \mathrm{E}, 24$.viii.2006, Nguyen LTP, Saito F \& Kojima J; Bak Kan: 1 ,, $\mathrm{Na}$ Lan, Lang Ngam, Ngan Son, 21 $48^{\prime} 15^{\prime} \mathrm{N}$, $105^{\circ} 44^{\prime} 30^{\prime} \mathrm{E}, 257 \mathrm{~m}, 17 . x .2015$, Nguyen LTP, Nguyen DD \& Nguyen MP; Son La: 2 우, Nam 
Pam, Muong La, 660m, 25.vii.2009, Nguyen LTP, Pham PH \& Kojima J; Phu Tho: 19 , Phuc Khanh, Yen Lap, 16.v.2016, Vu Thuong Thi; Vinh Phuc: 1 , Me Linh station, Phuc Yen, $x$. 2013, Dang Thi Hoa; Hoa Binh: 1q, Thuong Tien, Kim Boi, 26.iv.2012, Nguyen Lien Thi Phuong; Thanh Hoa: 1 , $\mathrm{Pu} \mathrm{Hu}$ NR, Quan Hoa, 20 29'10.7'N, 104 57'09.3'E, 243m, 11.vi. 2016, Truong LX, Nguyen DD, Tran NT \& Ha LN; 1 , , $1 \hat{\sigma} \mathrm{Pu} \mathrm{Hu}$ NR, Quan Hoa, $20^{\circ} 31^{\prime} 32.1$ 'N, 104 57'38.5'E, 284m, 12.vi. 2016, Truong LX, Nguyen DD, Tran NT \& Ha LN; 1 \%, Pu Hu NR, Quan Hoa, 20 33'56.0”N, $104^{\circ} 58$ '39.7'E, 255m, 14.vi.2016, Nguyen DD, Tran NT \& Ha LN; Dak Lak: 19 , Eo So NR, Ea So, Ea Kar, $12^{\circ} 58^{\prime} 44^{\prime \prime N}$, $108^{\circ} 40^{\prime} 10^{\prime \prime} \mathrm{E}, 347 \mathrm{~m}$, 15.iv.2015, Nguyen LTP, Nguyen DD \& Nguyen MP; Dak Nong: 1 ${ }^{\AA}$, Ta Dung NR, Dak
Som, Dak Giong, $11^{\circ} 50^{\prime} 16.1^{\prime \prime} \mathrm{N}, 107^{\circ} 59^{\prime} 16.7^{\prime \prime} \mathrm{E}$, 745m, 6.v.2016, Nguyen LTP, Nguyen DD \& Tran NT.

Diagnosis. This species is similar to $E$. diversicarinata but can be distinguished by the following characteristics:

Female: Apical margin of scutellum with a medially deep dimple (fig. 8). S6 without welldefined basal platform and well-developed laterobasal teeth, weak median carina apically (fig. 9). Central area of scutellum with coarse and sparse punctures (fig. 8). Mandible black (fig. 7).

Male: Marginal teeth of T7 very prominent (fig. 10). S6 with a rudimentary apical carina medially (fig. 10). Spots on lateral margins of scutellum dark red (in one specimen, scutellum wholly black).

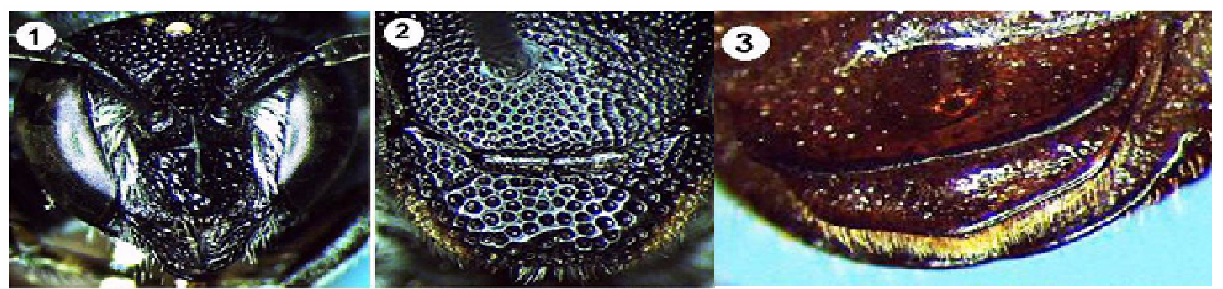

Figures 1-3. Euaspis aequicarinata (Female)

1. Head, frontal view; 2. Mesosoma and scutellum, dorsal view; 3. S6, lateroventral view.
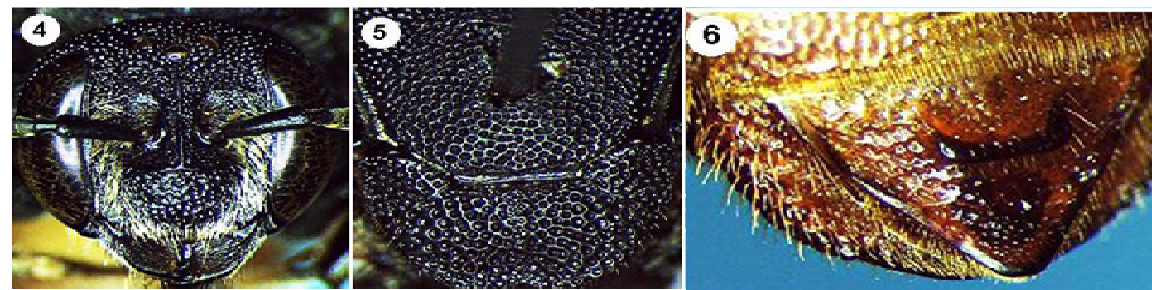

Figures 4-6. Euaspis diversicarinta (Female)

4. Head, frontal view; 5. Mesosoma and scutellum, dorsal view; 6. S6, lateroventral view

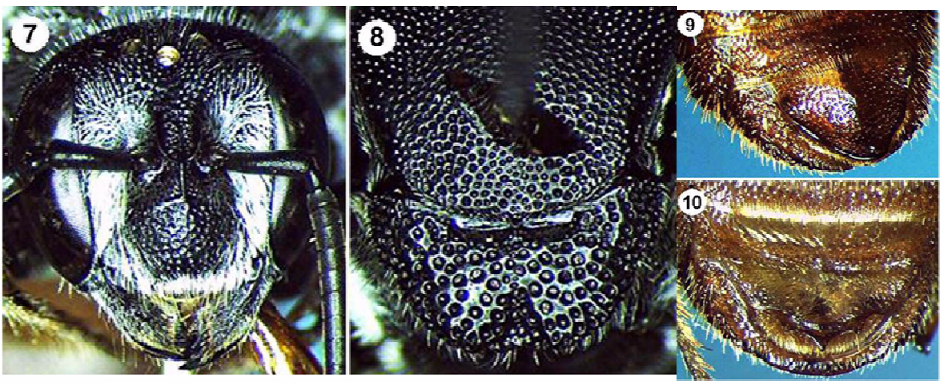

Figures 7-10. Euaspis polynesia (g-i: female, j: male)

7. Head, frontal view; 8. Mesosoma and scutellum, dorsal view; 9. S6, lateroventral view; 10. S6 and T7, lateroventral view. 
Acknowlegements: We are very grateful to James M. Carpenter (American Museum of Natural History, USA) for his valuable comments on the manuscript.

\section{REFERENCES}

Ascher J. S., Pickering J., 2016. Discover Life Bee species guide and world checklist (Hymenoptera: Apoidea: Anthophila). [Internet]. Discover Life, Accessed 10 August 2016, <http://www.discoverlife.org/ $\mathrm{mp} / 20 \mathrm{q}$ ? guide $=$ Apoidea_species\&flags $=\mathrm{HA}$ $\mathrm{S}>$.

Backer D. B. A., 1995. A review of the Asian species of the genus Euaspis Gerstäcker (Hymenoptera: Apoidea: Megachilidae). Zool. Med. Leiden, 69(22): 281-302.

Fabricius J. C., 1793. Entomologia Systematica Emendata et Aucta. Halfniae: Proft, 2, viii $+519 \mathrm{pp}$.

Gerstäcker C. E. A., 1958. Bearbeitung der von Peters aus Mossambique mitgebrachten Hymenopteren. Monatsber. Kön. preuss. Akad. Wissensch. Berlin, 1857: p. 461.

Le Xuan Hue, 2010. Discovery of a new species of the genus Bombus Latreille, 1802 (Hymenoptera: Apidae) from Vietnam. Tap chi Sinh hoc, 32(2): 21-23.

Khuat Dang Long, Nguyen Thi Phuong Lien,
Pham Thi Nhi, 2004. A Survey of Beneficial Hymenopteran bees and wasps, their use value in the buffer zone of Cuc Phuong National Park (North Vietnam). Sylvatrop, 14(1-2): 67-94.

Khuat Dang Long, Le Xuan Hue, Dang Thi Hoa, Pham Huy Phong, 2012. A preliminary study on bees (Hymenoptera: Apoidea: Apiformes) from North and North Central Vietnam. Tap chi Sinh hoc, 34(4): 419-426. http://dx.doi.org/10.15625/0866-7160/ v34n4.2676.

Michener C. D., 2007. The bees of the world, 2 nd ed. Johns Hopkins University Press. Baltimore. MD. xvi+[1]+953 pp.

Pasteels J., 1980. Révision du genre Euaspsis Gerstäcker (Hymenoptera, Apoidea, Megachilidae). Bull. Annls Soc. r. ent. Belg., 116: 73-89.

Ritsema C., 1874. [No title: description of Parevaspis gen. nov.]. Tijdschr. Ent., 17: pp. 1xx-lxxiii.

Vachal J., 1903a. Note sur Euaspis Gerst. et Ctenoplectra Sm., deux genres d'Hymenoptera mellifera peu ou mal connus. Bull. Soc. ent. France: 97.

Vachal J., 1903b. Note complémentaiet et rectificative sur Euaspis et Ctenoplectra [Hym.]. Bull. Soc. ent. France: 173. 


\section{VỀ VỊ TRÍ PHÂN LOẠI GIỐNG Euaspis Gerstäcker (Hymenoptera: Apoidea: Megachilidae) Ở VIẸTT NAM}

\section{Trần Thị Ngát, Khuất Đăng Long, Nguyễn Thị Phương Liên}

Viện Sinh thái và Tài nguyên sinh vật, Viện Hàn lâm $\mathrm{KH}$ và $\mathrm{CN}$ Việt Nam

\section{TÓM TẮT}

Bài báo đưa ra một số nhận xét về vị trí phân loại ba loài ong thuộc giống Euaspis Gerstäcker, 1858 (Hymenoptera: Apoidea: Megachilidae) ở Việt Nam. Đến nay, đã ghi nhận có ba loài thuộc giống này, đó là: $E$. aequicarinata Pasteels, E. polynesia Vachal và E. diversicarinata Pasteels. Trong số đó E. aequicarinata trước đây chỉ được ghi nhận ở vùng Tây Bắc (tỉnh Hòa Bình), nay được ghi nhận ở vùng Tây Nguyên của Việt Nam (Kon Tum); E. polynesia Vachal được ghi nhận ở toàn lãnh thổ Việt Nam; còn loài Euaspis basalis (Ritsema, 1874) trước đây đã được ghi nhận nhưng trên thực tế chưa thu được mấu của loài $E$. basalis, khi kiểm tra lại mẫu vật trước đây dựa trên đó để xác định loài này thực tế là loài Euaspis diversicarinata Pasteels, 1980 và loài này được xem như ghi nhận mới cho khu hệ của Việt Nam. Dựa trên mẫu ong cái, bài báo cũng đưa ra khóa định loại 3 loài đã biết thuộc giống Euaspis Gerstäcker ở Việt Nam và bổ sung mô tả loài $E$. diversicarinata.

Tù khóa: Apoidea, Megachilidae, Euaspis, ghi nhận mới, Việt Nam. 